\title{
DEMOGRAPHIC CHARACTERISTICS OF CONSUMERS IN CONSUMPTION OF ORGANIC FOOD PRODUCTS - CASE STUDY: SERBIA
}

\author{
Saša Raletić Jotanović ${ }^{1}$, Nikola Vuksanović ${ }^{2}$, Slobodan Živkucin ${ }^{3}$ \\ *Corresponding author E-mail: raletic.sasa84@gmail.com
}

\begin{tabular}{l} 
A R T I C L E I N F O \\
Original Article \\
Received: 13 April 2018 \\
Accepted: 12 September 2018 \\
doi:10.5937/ekoPolj1804371R \\
UDC 314:366.12(497.11) \\
\hline
\end{tabular}

Keywords:

organic food products, consumers, discouraging factors, motivating factors

JEL: J1, J19, E21, M3, Q1

\begin{abstract}
A B S T R A C T
The purpose of the paper is to determine the differences between demographic characteristics of consumers in relation to discouraging and motivating factors of consuming organic food products in Serbia. An empirical research was conducted in Serbia on a sample of 833 respondents, using e-questionnaire. T-test for independent samples was used. The results indicate that in relation to discouraging factors for consumption of organic food products there are differences in the demographic characteristics of consumers, exception is age. Also, in relation to motivation factors, differences exist in majority of consumers' demographic characteristics, except the level of education and place of residence. Practical application of the results enables adequately managed consumption of organic food products which directly affects the reduction of ecological, social, health and economic problems. On the other side, the theoretical application of the results enables the creation of a consumers' profile for organic food products.
\end{abstract}

(C) 2018 EA. All rights reserved.

\section{Introduction}

As a response to the deterioration of food quality and endangering of human health and the environment, the organic food was developed. Organic food is defined as

1 Saša Raletić Jotanović, Ph.D., Assistant, Higher education school for management and business communication, Department of Hospitality, 21205 Sremski Karlovci, Republic of Serbia, Mitropolita Stratimirovića Street 110; E-mail: raletic.sasa84@gmail.com, ORCID ID: /0000-0002-2181-1852

2 Nikola Vuksanović, Ph.D., Professor, Higher education school for management and business communication, Department of Hospitality, 21205 Sremski Karlovci, Republic of Serbia, Mitropolita Stratimirovića Street 110, E-mail: vuksanovicnikola85@gmail.com, ORCID ID: /0000-0001-8241-3228

3 Slobodan Živkucin, Ph.D., Professor, Higher education school for management and business communication, Department of Hospitality, 21205 Sremski Karlovci, Republic of Serbia, Mitropolita Stratimirovića Street 110; E-mail: slobodanzivkucin@gmail.com, ORCID ID: /0000-0001-6642-1041 
"food produced by farmers who emphasize the use of renewable resources and the conservation of soil and water to enhance environmental quality for future generations. Organic meat, poultry, eggs, and dairy products come from animals that are given no antibiotics or growth hormones. Organic food is produced without using most conventional pesticides; fertilizers made with synthetic ingredients or sewage sludge; bioengineering; or ionizing radiation." (https://www.nal.usda.gov)

Europe and Northern America absorb more than $90 \%$ of the world's offer for organic food (Willer, Lernoud, 2015, 25). These two regions are characterized by a continuous lack of required goods, considering that the production fails to reach the market demand. The biggest markets for organic food are USA, Germany and France (Figure 1) (Willer, Lernoud, 2015, 63). There are only few research done with regard to organic food consumption on the Balkan area. One of them was done by Sekovska and associates (2013) and they profiled organic food consumers and their preferences and attitudes regarding organic food.

Figure 1. Global market: Distribution of retail sales value by single markets in 2013.

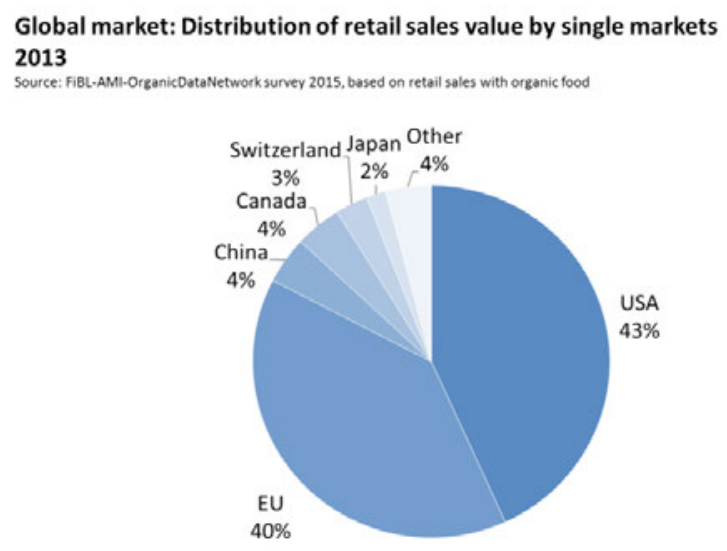

Source: Willer, Lernoud, 2015

Organic food in Serbia is consumed for less than $0.01 \%$ out of all consumed products (Huynh, Maslac, 2009, 7). Organic food consumption per capita in Serbia in 2010 was 5,5 euros (Willer, Lernoud, 2013, 73). In Serbia, organic food consumption is at a unenviable position and the following data confirms that - $80 \%$ to $90 \%$ of organic food produced in the Republic of Serbia is exported (Dragin, 2009, 8). However, regardless of the low power consumption, increase consumption of organic food products in the Republic of Serbia is certain (Figure 3a and 3b). 
Figure 3a. Tendency for organic food product consumption in the Republic of Serbia

\section{Perspectives SEE}

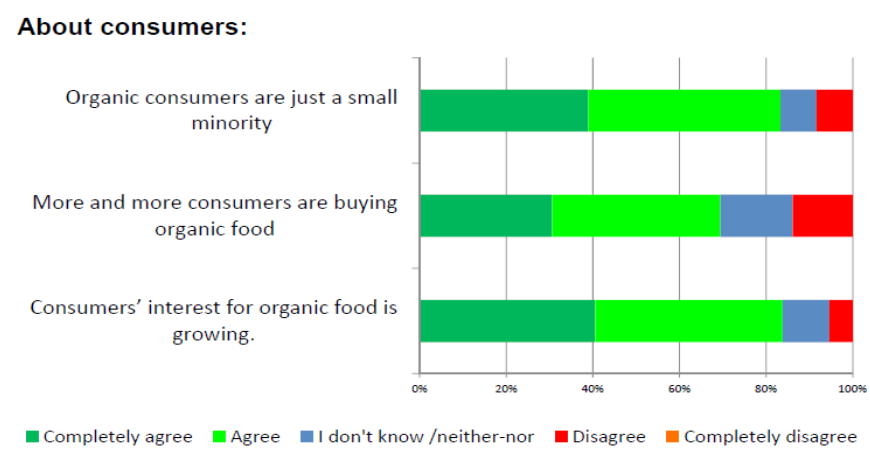

Source: Jansen, Schaer, 2012

Figure 3b. Tendency for organic food product consumption in the Republic of Serbia

\section{Perspectives SEE}

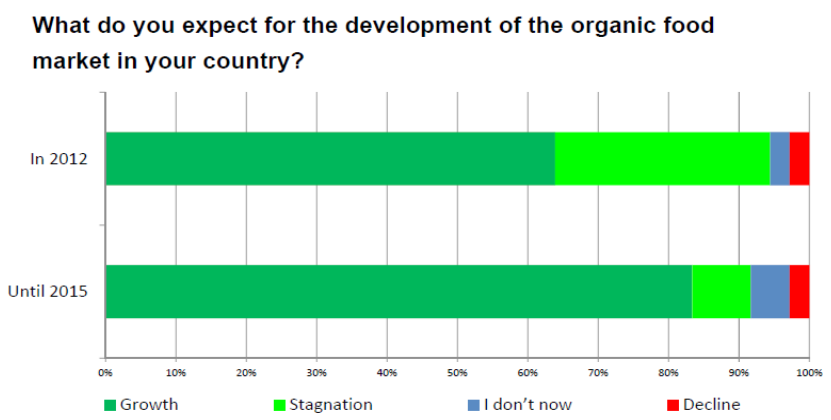

Source: Jansen, Schaer, 2012

Because of all mentioned above, it is necessary to efficiently manage factors that determine the use of organic food products in the Republic of Serbia. In order to make this achievable, it is necessary to know which factors are discouraging and which ones stimulate the use of organic food in the Republic of Serbia. As factors that discourage and motivate the demand for organic food products are affected by demographic characteristics of consumers (Kranjac et al., 2017; Vehapi, Dolićanin, 2016; Đokić et al., 2014), it is necessary to determine differences between demographic characteristics of consumers in relation to discouraging and motivating factors of consuming organic food products in Serbia, which is the aim of this paper. 


\section{Materials and methods}

Various research were conducted on the topic of factors which determinate consumption of organic food (Żakowska, 2009; Sampson, 2009; Aertsens et al., 2009; Rakić, Rakić, 2009; Gfk, 2011; Suprapto, Wijaya, 2012; Dumea, 2012; Mohamed et al., 2013; Pagiaslis, Krontalis, 2014; Vehapi, Dolićanin, 2016a; Kovljenić et al., 2016; Türk , Erciş, 2017). The most common factors that stand out are: price, educational promotion, trust in product certificate, habits, supply and lack of knowledge of consumers about organic food consumption.

Demographical factors are one of the most popular criterias for consumers'segmentation. They significantly determine attitudes and behaviour of consumers. Different research has proved a positive correlation between consumers' demographic characteristics and consumption of organic food (Sampson, 2009; Aertsens et al., 2009; Paço, Mário, 2009; Huynh, Maslac, 2009; Grk, 2012; Pagiaslis, Krontalis, 2014; Đokić et al., 2014; Vehapi, Dolićanin, 2016b; Kranjac et al., 2017).

Based on the above, following hypotheses were proposed:

H1 - There are statistically significant differences between demographic characteristics of consumers in relation to discouraging factors of organic food products consumption and,

$\mathbf{H 2}$ - There are statistically significant differences between demographic characteristics of consumers in relation to motivating factors of organic food products consumption.

\section{Sample}

The sample consists of 833 respondents from the territory of the Republic of Serbia. The sample is considered representative considering: the size of the sample compared to the basic set, nature of research, the number of variables being researched, variability of population characteristics that is being questioned and desired level of certainty. While creating the sample, method of randomly selection was used. Analyzed demographic characteristics are: gender, age, level of education, monthly income and place of residence.

Amongst the total number of respondents, $58 \%$ were women and $42 \%$ were men. Related to the age, $32 \%$ of respondents were between the age of 18 and $30,23 \%$ between 31 and 40 years old, $16 \%$ between 41 and 50 years old and $29 \%$ were older than 51 . The majority of the respondents have college education (31\%). The same percentage of respondents have completed high school and have university degree (23\%). A smaller number of respondents have completed university - master degree had $15 \%$ of the respondents, followed by respondents who hold $\mathrm{PhD}(5 \%)$. Based on the monthly income, the sample was distributed to $46 \%$ of respondents with average earnings, $37 \%$ with earnings below average and $17 \%$ of respondents with earnings above average. The monthly income of the respondents was measured based on the average earnings in the Republic of Serbia published in the publication of the Statistical Office of the Republic 
of Serbia (2016). The respondents had the possibility to declare if they had below, above or earnings similar to the republic average. Related to the place of residence, $78 \%$ of the respondents come from urban areas, while $22 \%$ come from suburbs.

\section{Instrument}

The instrument used in the research was a questionnaire, designed for the research purposes. The questionnaire was made based on the consulted literature, previous research and author's assumptions which are reformulated into questions. The questionnaire had two parts. The first part is related to the demographic characteristics of the respondents, which are presented in the research as independent variables. The second part deals with factors that determine organic food consumption i.e. factors that discourage and motivate organic food consumption in the Republic of Serbia. The answers were measured based on the Likert scale, 1 -I strongly disagree, 2 - I mostly disagree, 3 - neutral, 4- mostly agree, 5 - I completely agree.

\section{Procedure}

The survey was conducted on the territory of the Republic of Serbia. A team of ten researchers - previously trained graduated marketing students - undertook the survey during different days of the week (usually during afternoon and in the evening), over a period of two months (June-July, 2017). During the survey period, 1000 questionnaires were distributed, and 833 usable questionnaires were returned (usable response rate $=83.3 \%$.

\section{Data analysis and variables}

Data were analysed by means of software package SPSS: 20 (SPSS, 2008). The missing data were replaced by EM method, while analyses of deviated values indicate that there are none (Tabachnick, Fidell, 2007).

Independent variables in this study are the following: age, gender, level of education, monthly income and place of residence. There are also two dependent variables discouraging and motivating factors of organic food products consumption.

Differences between groups were analysed by T-test for independent samples, with the following factors: age, gender, level of education, monthly income and place of residence. Dependent variables were discouraging and motivating factors.

\section{Results}

Table 1. presents descriptive analysis of applied scales. Based on the values of multivariate skewness and kurtosis, it can be concluded that the answers of respondents on the "discouraging" and "motivating" scale do not deviate significantly as compared to normal distribution. 
Table 1. Descriptive scale indicators

\begin{tabular}{|l|c|c|c|c|c|c|c|c|}
\hline Scale & Min & Max & M & SD & Skew. & Kurt. & K-S & $\boldsymbol{\alpha}$ \\
\hline discouraging & 19.00 & 50.00 & 39.99 & 5.09 & -.625 & 1.066 & $0.492 *$ & 0.81 \\
\hline motivating & 17.00 & 49.00 & 37.59 & 4.09 & -.552 & 1.006 & $0.392 *$ & 0.80 \\
\hline
\end{tabular}

Note. ${ }^{*} p<0.1$ : Min. - minimal score; Max. - maximal score; $M$-arithmetic mean; SD - standard deviation; Skew. - Skewness; Kurt. - Kurtosis; K-S-Kolmogorov-Smirnov statistics; $\alpha$-scale reliability measured by internal consistency

Source: Authors based on data from survey research

Results obtained by descriptive statistics showed that discouraging factors of organic food consumption are: high price $43 \%$; insufficient market supply $22 \%$; consumer's lack of awareness of consumers $18 \%$; absence of buying habits $8 \%$, low confidence in the credibility of organic food $7 \%$ and others $2 \%$ (Figure 4 ).

Figure 4. Discouraging factors of organic food consumption in the Republic of Serbia

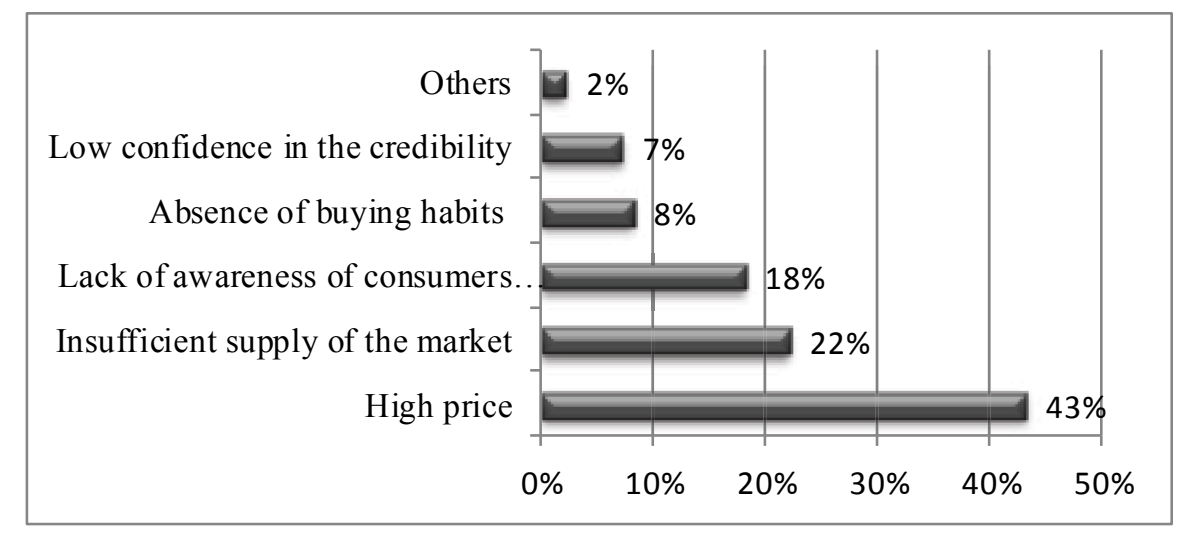

Source: authors

T-test for independent samples showed that differences in gender were set according to importance of discouraging factors of organic food consumption and significant differences were found in the factor of high price, $t(361))=-4.75, \mathrm{p}<0.01$ and consumer's lack of awareness about the advantages of organic food consumption, $t(361)=-2.81$, $\mathrm{p}<0.01$ (Table 2). These two factors were more important to women than to men. A result like this showed that depending on gender, importance of discouraging factors of high price and consumer's lack of awareness about the advantages of organic food consumption were high.

Table 2. Gender differences in discouraging factors

\begin{tabular}{|l|c|c|c|}
\hline Scale & t-test & df & Sig. \\
\hline high price & -4.75 & 361 & $<.01$ \\
\hline consumer's lack of awareness & -2.81 & 361 & $<.01$ \\
\hline
\end{tabular}

Source: authors 
The analysis of one factor of a variant showed that there were no significant differences between the five categories of consumers' age and discouraging factors of organic food consumption. A result like this showed that the importance of discouraging factors was not present depending on consumers' age.

The analysis of one factor of a variant showed that there were significant differences between the four categories of education and all the above-identified discouraging factors of organic food consumption: high price, $F(3,350)=3.90, p<0.01$, insufficient market supply, $\mathrm{F}(3,350)=4.68, \mathrm{p}<0.01$, consumer's lack of awareness about the advantages of organic food consumption $\mathrm{F}(3,350)=4.95, \mathrm{p}<0.01$, absence of buying habits $\mathrm{F}(3,350)=6.63, \mathrm{p}<0.01$, and low confidence in the credibility of organic food, $\mathrm{F}(3,350)=4.41, \mathrm{p}<0.01$ (Table 3$)$. The importance of all discouraging factors rose in the same direction as the level of education of the respondents. This means that level of the respondents' education determines the extent to which listed factors discourage organic food consumption.

Table 3. Education differences in discouraging factors

\begin{tabular}{|l|c|c|c|c|}
\hline Scale & F & df1 & df2 & Sig. \\
\hline high price & 3.90 & 3 & 350 & $<.01$ \\
\hline insufficient market supply & 4.68 & 3 & 350 & $<.01$ \\
\hline consumer's lack of awareness & 4.95 & 3 & 350 & $<.01$ \\
\hline lack of habit for buying & 6.63 & 3 & 350 & $<.01$ \\
\hline low confidence in the credibility & 4.41 & 3 & 350 & $<.01$ \\
\hline
\end{tabular}

Source: authors

Also, the analysis of one factor of a variant showed statistically significant differences between the three categories of monthly income of the respondents and a high price factor $F(3,359)=11.69, p<0.01$ as well in regard to insufficient market supply with organic food $\mathrm{F}(3,359)=14.31, \mathrm{p}<0.05$ (Table 4). The importance of a high price reduced, while importance of insufficient market supply with organic food increased with the increase of monthly income. This indicated that depending on respondent's monthly income, high price and insufficient market supply with organic food products had different level of importance as discouraging factor in consumption.

Table 4. Monthly income differences in discouraging factors

\begin{tabular}{|l|c|c|c|c|}
\hline Scale & F & df1 & df2 & Sig. \\
\hline high price & 11.69 & 3 & 359 & $<.01$ \\
\hline insufficient market supply & 14.31 & 3 & 359 & $<.05$ \\
\hline
\end{tabular}

Source: authors

T-test for independent samples showed that differences due to the place of residence were important as a discouraging factor of organic food consumption. Significant differences were found with factor of high price of organic food consumption, $t$ (363) $=-4.45, \mathrm{p}<0.01$, and the absence of buying habits for organic food, $t(363)=-2.87$, 
$\mathrm{p}<0.01$ (Table 5). Such a result showed that depending on a place of residence there was difference from factor of high price of organic food consumption as well as the absence of buying habits organic food. These factors were more important for the suburban habitants.

Table 5. Place of residence differences in discouraging factors

\begin{tabular}{|l|c|c|c|}
\hline Scale & t-test & df & Sig. \\
\hline high price & -4.45 & 363 & $<.01$ \\
\hline absence of buying habits & -2.87 & 363 & $<.01$ \\
\hline
\end{tabular}

Source: authors

According to the results of a descriptive statistics, consumers would buy more organic products if: prices were lower 34\%; they were more informed and educated about the usefulness and importance of organic food 29\%; they had more trust in certificate signifying organic food products $15 \%$; organic food offer were increased $12 \%$; there were health issues that could be regulated by healthy nutrition $7 \%$ and others $3 \%$ (Figure 5 ).

Figure 5. Motivating factors of organic food consumption in the Republic of Serbia

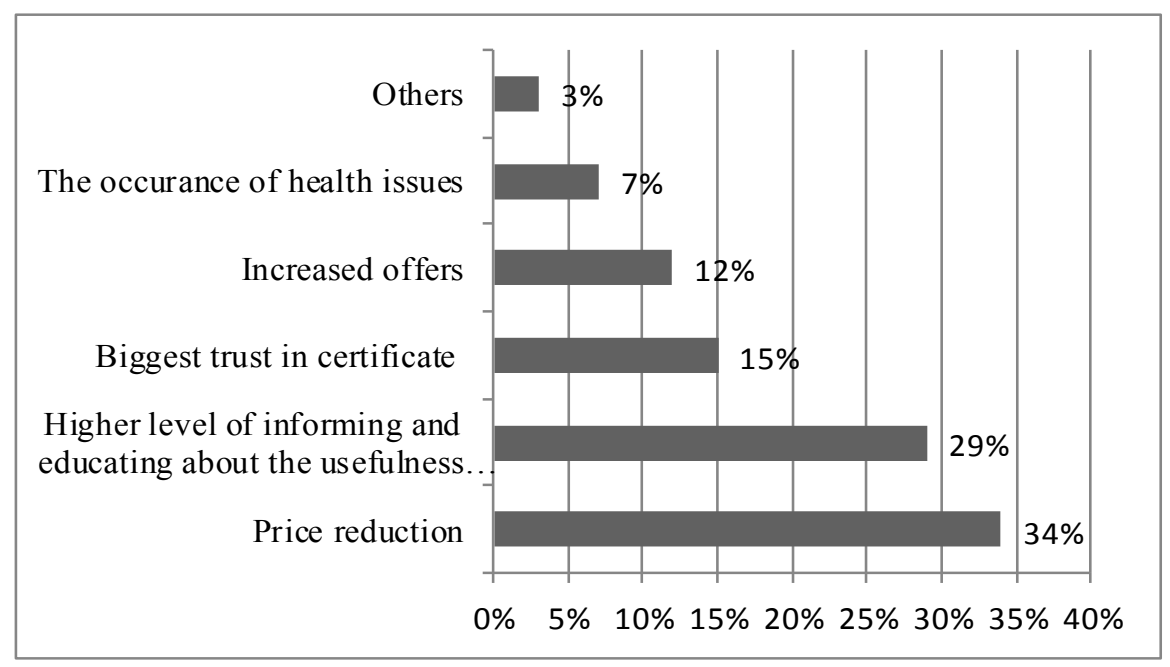

Source: authors

T-test for independent samples showed that differences between the gender of respondents and established motivating factors were revealed, and it was determined that there were significant differences among factors of a higher level of informing and education about the usefulness and importance of organic food, $t(370)=-2.33, p<0.05$ (Table 6). Thereby, degree of motivating factors of a higher degree of awareness and education about the usefulness and importance of organic food was higher for women. This showed that depending on the gender of respondents there was difference within the importance of a motivating factor of a higher degree of awareness and education about the utilities and importance of organic food products. 
Table 6. Gender differences in motivating factors

\begin{tabular}{|l|c|c|c|}
\hline Scale & t-test & df & Sig. \\
\hline higher level of informing and education & -2.33 & 370 & $<.05$ \\
\hline
\end{tabular}

Source: authors

The analysis of one factor of a variant showed that there were significant differences between the five categories of the age of respondents and a motivating factor of health issues, $F(3,335)=5.72, p<0.01$, whereby degree of motivating this factor increased with the increase of the age of respondents. This result showed that depending on the age of respondents there was difference within the degree of motivating caused by this factor.

The analysis of one factor of a variant showed that there were no significant differences between the four categories of education of respondents and motivating factors of organic food consumption. Such a result showed that the importance of motivating factors did not change depending on education of respondents.

Likewise, the analysis of one factor of a variant showed that there were significant differences between the three categories of monthly income in assessment of motivating factors: higher informing and education about the usefulness and importance of organic food, $\mathrm{F}(4,367)=5.86, \mathrm{p}<0.01$, biggest trust in certificate signifying organic food products $\mathrm{F}(4,367)=11.48, \mathrm{p}<0.01$, and price reduction, $\mathrm{F}(4,367)=3.22, \mathrm{p}<0.05$. Degree of motivating factors, higher informing and education about the usefulness and importance of organic food as well as trust in certificate signifying organic food products increased with the increase of monthly income, while the importance of factor of lowering price decreased. Such a result showed that degree to which respondents were motivating by three stated factors differs depending on monthly income of respondents.

Table 7. Monthly income differences in motivating factors

\begin{tabular}{|l|c|c|c|c|}
\hline Scale & F & df1 & df2 & Sig. \\
\hline higher level of informing and education & 5.86 & 4 & 367 & $<.01$ \\
\hline biggest trust in certificate & 11.48 & 4 & 367 & $<.01$ \\
\hline price reduction & 3.22 & 4 & 367 & $<.05$ \\
\hline
\end{tabular}

Source: authors

According to the results gained from T-test for independent samples, differences between the place of residence of respondents and determined motivating factors were set, implying that there were no significant differences in factors that stimulate organic food consumption and place of residence.

\section{Discussions}

Results obtained by descriptive statistics showed that the most discouraging factor for organic food consumption is high price, then insufficient market supply and the consumer's lack of awareness, while the most motivating factor is lower prices, than greater information and education about the usefulness and importance of organic food 
consumption and increase trust in certificate signifying organic food products. The results were confirmed by the previous research (Żakowska, 2009; Sampson, 2009; Aertsens et al., 2009; Rakić, Rakić, 2009; Gfk, 2011; Suprapto, Wijaya, 2012; Dumea, 2012; Mohamed et al., 2013; Pagiaslis, Krontalis, 2014; Vehapi, Dolićanin, 2016a; Kovljenić et al., 2016; Türk , Erciş, 2017).

The results indicate that there are differences in the demographic characteristic of consumers: gender, level of education, monthly income, place of residence, whereas there is no difference between age in relation to discouraging factors of organic food products consumption. The previous research (Sampson, 2009; Aertsens et al., 2009; Paço, Mário, 2009; Huynh, Maslac, 2009; Grk, 2012; Pagiaslis, Krontalis, 2014; Đokić et al., 2014; Vehapi, Dolićanin, 2016b; Kranjac et al., 2017) in great measure confirmed the obtained results. Respectively, previous research confirmed the obtained results in the part which referred to the established differences until it is not confirmed in the part referring to non-existence differences. Because all the above mentioned, the hypothesis 1 has been partially confirmed.

The results indicate that there are differences in the demographic characteristic of consumers: gender, age, monthly income, whereas there is no difference between level of education and place of residence in relation to motivating factors of organic products consumption. The previous research (Sampson, 2009; Aertsens et al., 2009; Paço, Mário, 2009; Huynh, Maslac, 2009; Grk, 2012; Pagiaslis, Krontalis, 2014; Đokić et al., 2014; Vehapi, Dolićanin, 2016b; Kranjac et al., 2017) confirmed the obtained results in the part which refers to the established differences until it is not confirmed in the part referring to non-existence differences. Based on the foregoing, the hypothesis 2 has been partially confirmed.

\section{Conclusion}

The results indicate that in relation to discouraging factors of organic food products consumption, there are differences in the demographic characteristic of consumers: gender, level of education, monthly income, place of residence, whereas there is no difference between age. Also, the results indicate that in relation to motivating factors of organic products consumption there are differences in the demographic characteristic of consumers: gender, age, monthly income, whereas there is no difference between level of education and place of residence.

\section{Practical application of the results}

The obtained data can be used to various market subjects (producers, traders, state institutions, international institutions, non-governmental organizations, etc.) in order to more effectively plan, implement and monitor marketing strategies and activities, all with the aim of increasing the consumption of organic food products. Further, the practical application of the results is reflected in the increase of sustainable consumption, which directly affects the reduction of ecological, social, health and economic problems. 


\section{Theoretical application of the results}

Theoretical application of the results is reflected in the creation of a profile of consumers of organic food products which as such can be applied in other studies.

\section{Limitations of the research}

- Subjectivity in answering, since the taking about organic food products is socially responsible behavior;

- The survey was conducted through a single measurement, which also affects the relevance of the results.

Conducted research opens door for future studies:

- which will analyze other variables that influence the increase or decrease of consumption of organic food products;

- which will analyze other demographic characteristics of the variable in the dossier on other motive and demotivation factors;

- comparation with other countries, e.g Sekovska and associates (2013) compared consumers from Macedonia and Serbia;

- longitudinal character of research, for example, 10 years.

\section{Conflict of interests}

The authors declare no conflict of interest.

\section{References}

1. Aertsens, J., Verbeke, W., Mondelaers, K., \& Van Huylenbroeck, G. (2009). Personal determinants of organic food consumption: a review. British Food Journal, 111(10), 1140-1167. DOI 10.1108/00070700910992961.

2. Đokić, I., Đokić, N., Pavlović, N., \& Žnideršić-Kovač, R. (2014). Promotion of organic food in Serbia: Implications from organic food consumers profile research. Economics of agriculture, 61(4), 837-849.

3. Dragin, S. (2009). Unlimited export potential of organic products. ExporterSIEPA, 14, 8-10.

4. Dumea, A.C. (2012). Factors influencing consumption of organic food in Romania. The USV Annals of Economics and Public Administration, 12, 1(15), 107-113.

5. Gfk, (2011). The Environment: Public Attitudes and Individual Behavior - A Twenty-Year Evolution. Gfk, Johnson a family company, New York.

6. Grk, S. (2012). Economy of plunge. Serbian Political Thought, 4, 171-196.

7. Huynh, H., \& Maslac, T. (2009). Organic Agriculture in Serbia. Washington: Global Agriculture Information Network.

8. Kovljenić, M., Raletić Jotanović, S., \& Nestorov-Bizonj, J. (2016). Predictors of buying agricultural and food products in Serbia. Agroekonomika, 45(72), 95-201. 
9. Kranjac, M., Vapa-Tankosić, J., \& Knežević, M. (2017). Profil of organic food consumers. Economics of agriculture, 64(2), 497-514.

10. Mohamed, A.R.S., Fathy, S.E., \& Abdulmohsin, R.A. (2013). Main factors influencing the spread and consumption of organic food in Saudi Arabia. Journal of Food Agriculture \& Environment, 11(1), 231- 233.

11. Paço, A., \& Mário, R. (2009). Green segmentation: an application to the Portuguese consumer market. Marketing Intelligence \& Planning, 37(3), 364379. doi.org/10.1108/02634500910955245

12. Pagiaslis, A., \& Krontalis, K.A. (2014). Green Consumption Behavior Antecedents: Environmental Concern, Knowledge, and Beliefs. Psychology and Marketing, 31(5), 335-348. doi.org/10.1002/mar.20698

13. Rakić, B., \& Rakić, M. (2009). Organic food marketing management. Economics of agriculture, 56(3), 453-468.

14. Sampson, L.K. (2009). Consumer analysis of purchasing behavior for green apparel. Thesis, North Carolina State University.

15. Sekovska, B., Branislav, V., \& Bunevski, G. (2013). Consumption of organic food in Macedonia and Serbia: similarities and differences. In Consumer attitudes to food quality products (pp. 239-245). Wageningen Academic Publishers, Wageningen.

16. Suprapto, B., \& Wijaya, T. (2012). Model of Consumer's Buying Intention towards Organic Food: A Study among Mothers in Indonesian. International Conference on Economics, Business and Marketing Management IPEDR, 29, 173-180.

17. Tabachnick, B.G., \& Fidell, L.S. (2007). Using Multivariate Statistics, 5th edn., Pearson, Boston, MA.

18. Türk , B., \& Erciş, A. (2017). 4A marketing mix impacts on organic food purchase intention. Serbian Journal of Management, 12(2), 189-199. Doi 10.5937/sjm12-10785.

19. United States Department of Agriculture, https://www.nal.usda.gov (January 31, 2018).

20. Vehapi, S., \& Dolićanin, E. (2016a). Analiza marketing instrumenata domaćih proizvođača organske hrane. Marketing, 47(1), 29-41.

21. Vehapi, S., \& Dolićanin, E. (2016b). Consumers behavior on organic food: Evidence from the Republic of Serbia. Economics of agriculture, 63(3), 871-889.

22. Willer, H., \& Lernoud, J. (2013). Current Statistics on Organic Agriculture Worldwide: Organic Area, Producers and Market, in Willer H., Lernoud J., Kilcher L.ed., The World of Organic Agriculture - Statistics and Emerging Trends 2013. IFOAM \& FiBL.

23. Willer, H., \& Lernoud, J. (2015): The World of Organic Agriculture 2015: Summery, in Willer H., \& Lernoud J., (2015): The World of Organic Agriculture Statistic and Emerging Trends 2015. FIBL \& IFOAM.

24. Żakowska, S.B. (2009). Factors underlying consumption of organic food in the opinion of Polish consumers. Agronomy Research, 7(2), 768-774. 